\title{
Gene for the Rat Atrial Natriuretic Peptide Is Regulated by Glucocorticoids In Vitro
}

David G. Gardner, Barry J. Gertz, Christian F. Deschepper, ${ }^{\star}$ and Daniel Y. Kim

Metabolic Research Unit, Department of Medicine, and *Department of Physiology, University of California at San Francisco, San Francisco, California 94143

\section{Abstract}

Glucocorticoids regulate the expression of the gene for atrial natriuretic peptide (ANP) in neonatal cardiocytes. Dexamethasone (Dex) increased cytoplasmic ANP mRNA levels and media ANP immunoreactivity in a dose-dependent fashion. These effects were not shared by the other classes of steroid hormones and were reversed by the glucocorticoid antagonist RU 38486.

The effect on ANP mRNA levels resulted, at least in part, from enhanced transcription of the gene. Dex effected a twofold increase in ANP gene activity assessed using a run-on transcription assay. The turnover of the ANP transcript was approximated using a standard pulse-chase technique. The half-life of the ANP mRNA was $18 \mathrm{~h}$ in hormone-free media. In the presence of Dex this half-life increased modestly to $30 \mathrm{~h}$, although the increase relative to the control did not reach statistical significance.

The effect of Dex at the level of the individual myocardial cell was assessed by in situ hybridization analysis using a specific $\left[{ }^{3} \mathbf{H}\right]$ cRNA probe. These studies demonstrated a significant level of ANP expression within a subpopulation of cells in the cultures. Exposure of the cells to Dex for $24 \mathrm{~h}$ did not recruit additional cells into the expressing pool $(27.3 \%$ cells/ high power field vs. $31.3 \%$ for the control) but did increase the level of expression (i.e., grain density) within individual cells.

These findings indicate that glucocorticoids stimulate expression of the ANP gene directly at the level of the myocardial cell. This results predominantly from transcriptional activation in cells already expressing the gene rather than through recruitment of previously quiescent cells.

\section{Introduction}

Atrial natriuretic peptide (ANP) ${ }^{1}$ is a hormone that possesses significant activity in the cardiovascular, renal and endocrine systems. It has potent smooth muscle relaxant (1) and natriuretic (2) activity, and it suppresses the secretion of renin (3), vasopressin (4), and aldosterone $(5,6)$, three hormones that

Dr. Gertz' present address is Merck Sharp \& Dohme Research Laboratories, P. O. Box 2000, WBD-242, Rahway, NJ 07065-09145. Address reprint requests to Dr. Gardner, Metabolic Research Unit, 671 HSE, University of California, San Francisco, San Francisco, CA 94143.

Received for publication 1 December 1986 and in revised form 1 April 1988.

1. Abbreviations used in this paper: ANP, atrial natriuretic peptide; BUdR, bromodeoxyuridine; Dex, dexamethasone; DOCA, deoxycorticosterone acetate; GRE, glucocorticoid responsive elements.

J. Clin. Invest.

(C) The American Society for Clinical Investigation, Inc. $0021-9738 / 88 / 10 / 1275 / 07 \quad \$ 2.00$

Volume 82, October 1988, 1275-1281 function to maintain intravascular volume. The bioactive peptide appears to be derived from the carboxyterminus of a much larger precursor molecule whose structure has recently been elucidated through the cloning of the ANP cDNA (7-10). The genes for human (11-13), mouse (13), and rat (14) ANP have been cloned and sequenced. Noteworthy, within the second intron of both the rat and human gene there are short stretches of DNA that bear some homology to the consensus sequence of the so-called glucocorticoid regulatory elements (15-17), raising the intriguing possibility that the genes for ANP might be regulated by steroid hormones.

Glucocorticoids have recently been shown to increase circulating levels of ANP in the rat $(21,22)$. Glucocorticoids administered in vivo also increase the levels of ANP mRNA in atrial and extraatrial tissues $(22,23)$. The present study demonstrates that these effects take place directly at the level of the ANP-producing cell. Glucocorticoids increase ANP secretion, ANP mRNA levels, and relative transcription rates of the ANP gene in primary cultures of rat cardiocytes, suggesting that glucocorticoids directly regulate the expression of this gene.

\section{Methods}

Restriction enzymes, $S_{1}$ nuclease, and calf intestinal alkaline phosphate were purchased from Bethesda Research Laboratories (Gaithersburg, MD) or Boehringer-Mannheim (Indianapolis, IN). [ $\left.\alpha^{32} \mathrm{P}\right]-$ Deoxyribonucleotides and $\left[{ }^{3} \mathrm{H}\right]$ uridine were obtained from Amersham Corp., Arlington Heights, IL; $\left[\gamma^{32}\right.$ P]ATP was purchased from ICN Pharmaceuticals (Cleveland, $\mathrm{OH}$ ). The rat ANP gene was supplied to us as a 4.2-kb Eco RI fragment subcloned in pBR322 by Dr. B. Greenberg, while recombinant human pro-ANP was generously provided to us by Dr. R. Scarborough of California Biotechnology, Inc. (Mountain View, CA). RU 38486 was a gift of Roussel Pharmaceuticals (Romaineville, France). Other reagents were purchased from standard commercial suppliers and represent the best grades commercially available.

Cell preparation. Neonatal cardiocytes were prepared using a modification of the procedure described by Simpson and Savion (24). In brief, 1-d-old rat pups were killed and intact hearts, including atria, were excised using sterile technique. Cells were dispersed using alternating cycles of trypsin $(0.1 \%)$ digestion and mechanical disruption (trituration through a $10-\mathrm{ml}$ wide bore pipette (Falcon Labware, Oxnard, CA). After removal of tissue debris (Cellector filter, 30 mesh; Belco, Vineland, NJ), the cells were pooled and preplated for $30 \mathrm{~min}$ to allow for attachment of nonmyocardial cells to the tissue culture plate (24). Myocardial cells were decanted from the plate, plated in DME H21 medium containing $10 \%$ FCS and $0.1 \mathrm{mM}$ bromodeoxyuridine (BUdR; to suppress fibroblast growth) for $48 \mathrm{~h}$. Based on immunofluorescent analysis of individual cells for cardiac myosin (24), $70 \%$ of adherent cells in this preparation represent myocardial cells. Addition of dexamethasone (Dex) $\left(10^{-7} \mathrm{M}\right)$ had no effect on the relative percentage of myocardial cells in the preparation (data not shown). After $48 \mathrm{~h}$ the media was changed to a "deinduction" media consisting of DME H21; 5\% serum substitute lacking thyroxine, cortisol, or insulin (25); $5 \%$ "stripped" serum, previously treated to remove endogenous thyroid and steroid hormones (26); $5 \mu \mathrm{g} / \mathrm{ml}$ insulin; $5 \mu \mathrm{g} / \mathrm{ml}$ transferrin; $750 \mathrm{nM}$ vitamin $B_{12}$. Cells were left in this media for $48 \mathrm{~h}$, at which 
point the media was replaced with fresh deinduction media, with or without the addition of exogenous hormone as dictated by the experimental protocol. Steroids were dissolved in $0.1 \%$ ethanol; $0.1 \%$ ethanol was added to all control cells.

To generate enriched preparations of atrial or ventricular cells, intact neonatal hearts were divided slightly below the atrioventricular groove. The lower portion, devoid of atrial tissue was used to generate the ventricular cardiocyte preparation. The upper portion of the heart ( $\simeq 30 \%$ of the total mass) was digested independently to generate an atrial cardiocyte-enriched preparation. To generate the nonmyocardial cell cultures cells collected on the dish surface during the preplating step (see above) were allowed to divide in culture for $\simeq 3 \mathrm{wk}$. This procedure enriched the preparation for nonmyocardial cellular elements by effectively diluting out residual myocardial cells as a function of time in culture. These cells were split into small dishes and treated as were the cardiocytes above except that BUdR was excluded from the media.

Isolation of RNA. Cells were harvested in cold PBS by mechanically scraping the surface of the tissue culture plate. Cells were pelleted (1,500 $\mathrm{g}$ for $5 \mathrm{~min}$ ) and resuspended in $250-300 \mu$ l of lysis buffer (10 mM Tris $\mathrm{HCl}$, pH 7.5; 1 mM EDTA; $1 \%$ NP-40; 5 mM DTT and RNAsin [1 U/ $\mu$; Promega Biotec, Madison, WI]), vortexed gently, and kept on ice for $5 \mathrm{~min}$. After a second vortexing the cells were replaced on ice for $5 \mathrm{~min}$, then centrifuged at $12,000 \mathrm{~g}$ for $1 \mathrm{~min}$. $250 \mu \mathrm{l}$ of supernatant were removed and immediately extracted with equal volumes of phenol and chloroform. A second extraction with chloroform was followed by ethanol precipitation. RNA's were resuspended in 10 $\mathrm{mM}$ Tris $\mathrm{HCl}, \mathrm{pH} 7.5$, and $1 \mathrm{mM}$ EDTA and quantitated by absorption at $260 \mathrm{~nm}$.

$S_{1}$ nuclease and blot-hybridization analysis. $S_{1}$ nuclease analysis was carried out as described previously (27) using an 840-bp Eco RI$\mathrm{Bgl}$ II fragment that spans the 5'-end of the rat ANP gene (14). Blot hybridization analysis was carried out using the technique of Thomas (28). For dot-hybridization analysis the technique of Berents et al. (29) was employed. Hybridization was carried out with a rat ANP cDNA probe radiolabeled by nick translation. Relative ANP transcript levels were assessed by densitometric scanning of the major nuclease $S_{1}$ protected product ( $\sim 195$ nucleotides) or hybridizing dots on the autoradiographs. Differences were calculated using one-way analysis of variance and the Newman-Keuls test.

Radioimmunoassay and immunoprecipitation analysis. Radioimmunoassay of ANP was performed as described previously (27). To avoid concerns about serum-mediated processing of ANP immunoreactivity secreted into the tissue culture media, totally defined serumfree media (25) was employed in these studies.

Aliquots of culture media were stored frozen at $-20^{\circ} \mathrm{C}$ until assay. For radioimmunoassay 5-25 $\mu \mathrm{l}$ of media and $500 \mu \mathrm{l}$ of rabbit antisera (1:1,400 final dilution in PBS containing $50 \mathrm{mM}$ EDTA and $0.1 \%$ BSA) directed against a 25 amino acid carboxyterminal fragment of the rANP molecule (residues 4-28, reference 30 ) were incubated together at $4^{\circ} \mathrm{C}$ for $24 \mathrm{~h}$. At that point $10^{4} \mathrm{cpm}{ }^{125} \mathrm{I}$-rANP, iodinated with chloramine $t$ (sp act $\simeq 300 \mu \mathrm{Ci} / \mu \mathrm{g}$ peptide), was added in a volume of $100 \mu \mathrm{l}$ and the incubation continued an additional $24 \mathrm{~h}$. Bound and free ligand were separated with dextran-coated charcoal. Samples displaced radiolabeled tracer from the antibody in parallel with the standard curve. Sensitivity routinely was $20-40 \mathrm{pg} /$ tube. Recombinant human pro-ANP (128 amino acids) was $\sim 10 \%$ as effective, on a molar basis, as the 25 amino acid peptide in displacing the trace from the antibody. Dex, alone, at micromolar concentrations had no displacement activity in the radioimmunoassay.

Immunoprecipitation of ANP released into the culture media was carried out essentially as described by Bloch et al. (31) using an antiserum raised against thyroglobulin-coupled rat ANP. Myocardial cell cultures were pulsed for $2 \mathrm{~h}$ with $\left[{ }^{35} \mathrm{~S}\right]$ cysteine, at which point the label was removed. The media was collected after an additional 3-h incubation, immunoprecipitated, and analyzed by SDS-PAGE.

Run-on transcription assay. Neonatal cardiocytes $\left(4 \times 10^{6}\right.$ per plate), prepared as described above and maintained in deinduction medium for $72 \mathrm{~h}$, were exposed to $1 \mu \mathrm{M}$ Dex or fresh deinduction medium for $5 \mathrm{~h}$ at $37^{\circ} \mathrm{C}$. All subsequent procedures were performed at $0-4^{\circ} \mathrm{C}$. The incubation was terminated by washing and harvesting the cells in PBS. After centrifugation the cells were resuspended and washed in buffer $(10 \mathrm{mM}$ Tris $\cdot \mathrm{HCl} \mathrm{pH} 7.9,10 \mathrm{mM} \mathrm{NaCl}, 6 \mathrm{mM}$ $\mathrm{MgCl}_{2}, 5 \mathrm{mM}$ DTT). After repeat centrifugation the cells were lysed by vortexing in $1.5 \mathrm{ml}$ of the same buffer containing $0.5 \%$ NP-40. After 10 min on ice and repeat vortexing the cells were further disrupted by 12 strokes with the A pestle in a Dounce homogenizer. Nuclei were collected by low speed centrifugation, washed with lysis buffer without $\mathrm{NP}-40$, and, after repeat centrifugation, resuspended in $100 \mu \mathrm{l}$ of transcription buffer ( $50 \mathrm{mM}$ Tris $\cdot \mathrm{HCl}$ pH 7.9, $100 \mathrm{mM} \mathrm{KCl}, 12.5 \%$ glycerol, $6 \mathrm{mM} \mathrm{MgCl}_{2}, 1 \mathrm{mM} \mathrm{MnCl}, 0.2 \mathrm{mM}$ EDTA, $20 \mathrm{mM} \mathrm{NH}_{4} \mathrm{SO}_{4}, 6$ $\mathrm{mM} \mathrm{NaF}, 10 \mu \mathrm{M}$ creatine phosphate, $100 \mu \mathrm{g} / \mathrm{ml}$ of creatine phosphokinase, $10 \mathrm{mM}$ DTT, $2.5 \mathrm{mM}$ ATP, $0.6 \mathrm{mM}$ CTP, $250 \mu \mathrm{Ci}$ each of $\left[\alpha^{32} \mathrm{P}\right] \mathrm{UTP}$ and $\left[\alpha^{32} \mathrm{P}\right] \mathrm{GTP}(400 \mathrm{Ci} / \mu \mathrm{mol})$, and $1 \mathrm{U} / \mu \mathrm{l}$ RNAsin $)$.

After incubation at $30^{\circ} \mathrm{C}$ for $30 \mathrm{~min}$ an equal volume of DNAse buffer ( $50 \mathrm{mM}$ Tris $\cdot \mathrm{HCl} \mathrm{pH} 7.9,2 \mathrm{mM} \mathrm{CaCl}, 5 \mathrm{mM} \mathrm{MgCl} 2,1 \mathrm{mg} / \mathrm{ml}$ yeast tRNA, $10 \mathrm{mM}$ DTT, $2 \mathrm{U} / \mu \mathrm{l}$ RNAsin) containing $100 \mu \mathrm{g} / \mathrm{ml}$ (final concentration) RNAse-free DNAse (Cooper Biomedical, Malvern, PA) was added and the incubation continued for $15 \mathrm{~min}$ at $37^{\circ} \mathrm{C}$. At that point an equal volume of $2 \times \mathrm{PK}$ buffer $(200 \mathrm{mM}$ Tris $\cdot \mathrm{HCl} \mathrm{pH}$ 7.5, $25 \mathrm{mM}$ EDTA, $300 \mathrm{mM} \mathrm{NaCl}, 1 \%$ SDS) plus $50 \mu \mathrm{g} / \mathrm{ml}$ (final concentration) heat-treated proteinase $\mathrm{K}$ was added and the incubation continued for $45 \mathrm{~min}$ at $37^{\circ} \mathrm{C}$. After extraction with phenol/chloroform, ${ }^{32} \mathrm{P}$-labeled RNA was further purified by the method of Matrisian et al. (32). Radioactivity incorporated into RNA was monitored using DE 81 filters (Whatman Inc., Clifton, NJ) as per Maxwell et al. (33).

Relative incorporation was determined by hybridizing the $\left[{ }^{32} \mathrm{P}\right]-$ RNA to nitrocellulose filters prepared according to Kafatos et al. (34) containing $4 \mu \mathrm{g}$ of linearized plasmid harboring the rANP $\mathrm{cDNA}$ or vector alone (SP65). One of each filter was included in the hybridizations to allow correction for nonspecific binding. Hybridizations were performed for $72 \mathrm{~h}$ at $45^{\circ} \mathrm{C}$ according to McKnight and Palmiter (35), washed as described, air dried and dissolved in Filtron X-100. Bound radioactivity was determined by scintillation counting.

Pulse chase analysis. Cells $\left(5 \times 10^{6} /\right.$ plate $)$ were placed into deinduction media for $48 \mathrm{~h}$. Media was changed and the incubation was continued in the same media with or without $10^{-6} \mathrm{M}$ Dex for an additional $24 \mathrm{~h}$. After $24 \mathrm{~h}$ the media was removed and $2 \mathrm{ml}$ of fresh deinduction medium (with or without $10^{-6} \mathrm{M}$ Dex) containing 1 $\mathrm{mCi} / \mathrm{ml}\left[{ }^{3} \mathrm{H}\right]$ uridine (pulse medium) was added and the incubation was continued for an additional $6 \mathrm{~h}$. The pulse medium was removed and the cells were washed with deinduction medium containing $5 \mathrm{mM}$ uridine and $5 \mathrm{mM}$ cytidine (42), with or without Dex, then incubated in the same medium for an additional $16 \mathrm{~h}$. At that point the first cells were harvested from each group (zero time, control, and Dex) and fresh deinduction media containing $2 \mathrm{mM}$ uridine and $2 \mathrm{mM}$ cytidine was added (lower concentrations of uridine and cytidine were employed to minimize toxicity to the cells). Cells were harvested at 24,48 , and $55 \mathrm{~h}$ into the chase. Cytoplasmic RNA was isolated as described above and quantitated by absorption at $260 \mathrm{nM}$. Hybridizations using rANP cDNA bound to nitrocellulose filters and subsequent washes were carried out as described in the preceding section. Filters were counted after dissolution in Filtron X. Results are corrected for nonspecific binding to filters containing plasmid DNA alone.

In situ hybridization histochemistry. To construct vectors suitable for production of radiolabeled RNA probes, an $800 \mathrm{bp} \mathrm{Eco} \mathrm{RI-Hind} \mathrm{III}$ rANP cDNA fragment was cloned between the Eco RI and Hind III sites of SP64 or SP65. This positioned the sequences in the correct orientation for synthesis of the $\left[{ }^{3} \mathrm{H}\right] \mathrm{cRNA}$ (SP64-rANP) or $\left[{ }^{3} \mathrm{H}\right] \mathrm{mRNA}$ (SP65-rANP) using the SP-6 polymerase promoter present in each vector. Synthesis of the probes was carried out using $0.5 \mu \mathrm{g}$ of linearized template (i.e., Eco RI cut SP64-rANP or Hind III cut SP65rANP); SP-6 buffer (40 mM Tris-HCl, pH 7.9, $6 \mathrm{mM} \mathrm{MgCl}_{2} ; 2 \mathrm{mM}$ spermidine; all final concentrations); $50 \mu \mathrm{Ci}\left[{ }^{3} \mathrm{H}\right] \mathrm{UTP} ; 0.5 \mathrm{mM}$ CTP, GTP, and ATP; 10 mM DTT; RNAsin (50 U/reaction; Promega Bio- 
tec); $15 \mathrm{U} \mathrm{SP}-6$ polymerase. Reactions were carried out at $37^{\circ} \mathrm{C}$ for 60 min, then treated with $20 \mathrm{U}$ DNAse I for $10 \mathrm{~min}$ at $37^{\circ} \mathrm{C}$ to digest residual plasmid DNA. Products were repetitively precipitated with ethanol (three times) to eliminate residual free nucleotide.

Atrial enriched myocardial cells were cultured on glass microscope slide chambers (Lab-Tek Div. Miles Laboratories, Naperville, IL; VWR Scientific, San Francisco, CA) under media conditions identical to those employed for RNA analysis (see above). The slides were fixed in $4 \%$ paraformaldehyde and dehydrated sequentially in 70 and $100 \%$ ethanol for $5 \mathrm{~min}$ each at room temperature. The sections were then digested with $2.5 \mu \mathrm{g} / \mathrm{ml}$ proteinase $\mathrm{K}$ at $37^{\circ} \mathrm{C}$ for $5 \mathrm{~min}$, washed twice for 5 min with a $2 \times$ SSC solution $(300 \mathrm{mM}$ sodium chloride, $30 \mathrm{mM}$ sodium citrate, $\mathrm{pH} 7.0$ ), and acetylated by incubation in $0.1 \mathrm{M}$ triethanolamine containing $0.5 \%$ acetic anhydride. After prehybridization for $2 \mathrm{~h}$ at $45^{\circ} \mathrm{C}$ in buffer containing $4 \times \mathrm{SSC}, 1 \times$ Denhardt's solution $(0.2 \%$ polyvinylpyrrolidone/0.02\% Ficoll/0.02\% BSA), 50\% formamide, 50 $\mu \mathrm{g} / \mathrm{ml}$ yeast tRNA and $50 \mu \mathrm{g} / \mathrm{ml}$ polyadenylic acid, the buffer was aspirated and the sections were covered with $20 \mu \mathrm{l}$ of buffer containing the $\left[{ }^{3} \mathrm{H}\right]$ radiolabeled rANP $\mathrm{cRNA}$ or mRNA probe $(\sim 100,000 \mathrm{cpm}$ per slide) and topped with glass coverslips. Slides were incubated overnight at $45^{\circ} \mathrm{C}$ in a humidified environment. After posthybridization treatment with ribonuclease $A\left(20 \mu \mathrm{g} / \mathrm{ml}\right.$ at $37^{\circ} \mathrm{C}$ for $\left.60 \mathrm{~min}\right)$, the unhybridized probe was removed by washing the sections in $0.2 \times$ SSC at $45^{\circ} \mathrm{C}$ with frequent changes of buffer. After washing, the slides were air dried and dipped in Ilford $\mathrm{K} 5$ photographic emulsion (diluted $1: 1$ in $\mathrm{H}_{2} \mathrm{O}$ at $37^{\circ} \mathrm{C}$ ) in the darkroom. The slides were then air dried for $2 \mathrm{~h}$ in the dark and stored desiccated at $4^{\circ} \mathrm{C}$. After 1 wk exposure, the slides were developed, dehydrated in graded alcohols and xylene, and mounted with Permount. The slides were counterstained with hematoxylin and examined under lightfield illumination in a Zeiss photomicroscope.

\section{Results}

As shown in Fig. 1 the major and minor ANP transcripts in neonatal cardiocytes appear to be very similar to those previously identified in mature adult atria (27). The major transcripts protect a labeled fragment $\sim 190-195$ nucleotides in length mapping their 5'-termini to a position $\sim 20-30 \mathrm{nu}-$ cleotides downstream from the genomic TATAAAA sequence, which is thought to dictate the start site of transcription (14). The minor transcripts map 10 and 80 nucleotides further upstream. In addition the overall size of the ANP transcript (950-1050 nucleotides, see below) is very similar to that previously reported in the mature atria (27) confirming the findings of Bloch et al. (31).

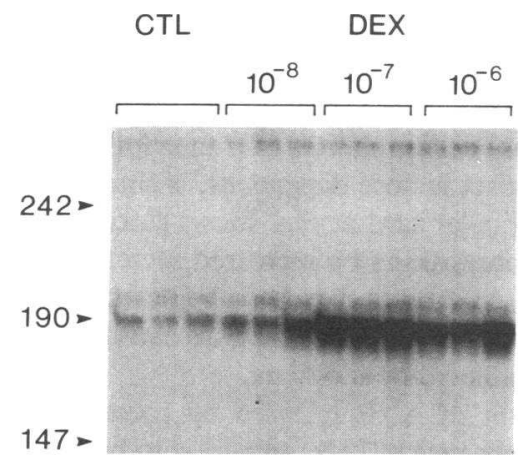

Figure 1. Effects of Dex on ANP gene expression. Neonatal cardiocytes $\left(4 \times 10^{6} /\right.$ plate $)$ were exposed to varying amounts of Dex in deinduction media for 24 h. Cells were harvested, total cytoplasmic RNA was isolated, and nuclease $S_{1}$ analysis was carried out as described using $5 \mu \mathrm{g}$ of RNA per individual

sample. Each lane represents RNA collected from an independent culture dish. Numbers in vertical column represent size markers in base pairs.
Table I. Effect of Dex on Secretion of ANP In Vitro

\begin{tabular}{lcc}
\hline & \multicolumn{2}{c}{ Media immunoreactive ANP $(\mathrm{pg} / 0.1 \mathrm{ml})$} \\
\cline { 2 - 3 } & $2 \mathrm{~h}$ & $48 \mathrm{~h}$ \\
\hline Control & $92 \pm 21$ & $2,200 \pm 1,000$ \\
Dex $10^{-8} \mathrm{M}$ & $121 \pm 33$ & $3,700 \pm 1,100$ \\
Dex $10^{-7} \mathrm{M}$ & $178 \pm 32^{*}$ & $5,300 \pm 2,500^{\ddagger}$ \\
Dex $10^{-6} \mathrm{M}$ & $148 \pm 55^{*}$ & $4,500 \pm 2,200$ \\
\hline
\end{tabular}

Cardiocytes were incubated in media containing $10 \%$ serum substitute with or without Dex for the intervals indicated. $100-\mu$ aliquots were taken at 2 and $48 \mathrm{~h}$ for ANP RIA. Results are expressed as mean $\pm \mathrm{SD}, \mathrm{n}=5$.

${ }^{*} \alpha<0.01,{ }^{\ddagger} \alpha<0.05$ compared to control value.

The glucocorticoid dexamethasone increased ANP mRNA levels in a dose-related fashion between $10^{-8}$ and $10^{-6} \mathrm{M}$ Dex peaking at a level approximately six-fold above controls ( $\alpha$ $<0.01$; Fig. 1). Of note, Dex did not affect the choice of start sites (both the major and minor start sites increased proportionally) nor the overall size of the ANP transcripts. Cultures selectively enriched for ventricular myocardial cells (i.e., atrial tissue excluded from the preparation) also displayed a dosedependent increase in ANP mRNA levels after treatment with Dex (data not shown). Basal levels of ANP mRNA were considerably lower in the ventricular cells. Dex increased these levels approximately two- to threefold with a peak response at $\sim 10^{-8} \mathrm{M}$. No ANP gene expression was detected in either untreated or Dex-induced nonmyocardial cells (data not shown).

The increase in ANP mRNA accumulation was accompanied by increased secretion of immunoreactive peptide. Shown in Table I, media ANP immunoreactivity increased in a dosedependent fashion after $48 \mathrm{~h}$ of exposure to the glucocorticoid. Immunoprecipitation analysis revealed that the predominant immunoreactive radiolabeled species migrated at $17 \mathrm{kD}$, the size of pro-ANP, as reported previously by others (31). This pattern persisted in the presence or the absence of Dex (data not shown).

The increase in ANP mRNA appeared to be relatively specific for glucocorticoids. Deoxycorticosterone acetate (DOCA), progesterone (Prog), and estradiol 17- $\beta\left(\mathrm{E}_{2}\right)$, at micromolar concentrations, effected no change in ANP tran-

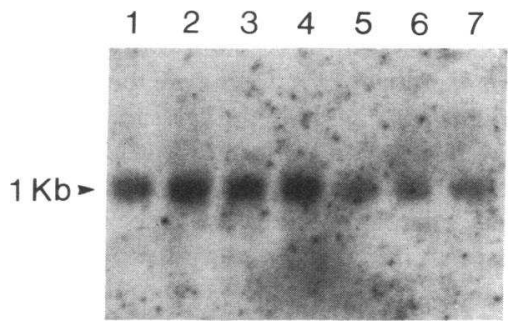

Figure 2. Specificity of steroid hormone effect. Pooled total RNA (15 $\mu \mathrm{g})$ from control or steroid-treated cells was denatured in glyoxal and subjected to Northern blot-hybridization analysis using a rANP cDNA probe. Lane 1 ,

control; lane 2, Dex $10^{-8} \mathrm{M}$; lane 3, Dex $10^{-7} \mathrm{M}$; lane 4, Dex $10^{-6}$ $\mathrm{M}$; lane 5, DOCA $10^{-6} \mathrm{M}$; lane 6, Prog $10^{-6} \mathrm{M}$; lane $7=\mathrm{E}_{2} 10^{-6} \mathrm{M}$. Major transcript migrates at 950-1050 nucleotides as judged from independently run DNA markers. 
Table II. Effect of RU 38486 on Dex Induction of ANP

\begin{tabular}{|c|c|c|c|}
\hline Treatment & $\begin{array}{c}\text { Media ANP immunoreactivity } \\
\pm \text { SD }\end{array}$ & Treatment & $\begin{array}{c}\text { ANP mRNA } \\
\text { (arbitrary densitometric units) } \pm \text { SD }\end{array}$ \\
\hline & $n g / m l / 24 h$ & & \\
\hline Ctl & $16.7 \pm 3.3$ & Ctl & $29.3 \pm 3.0$ \\
\hline Dex $10^{-7} \mathrm{M}$ & $30.8 \pm 3.8^{*}$ & Dex $10^{-6} \mathrm{M}$ & $54.1 \pm 8.8^{*}$ \\
\hline Dex $10^{-7} \mathrm{M}+$ RU $3848610^{-6} \mathrm{M}$ & $15.8 \pm 5.8^{\ddagger}$ & Dex $10^{-6} \mathrm{M}+$ RU $3848610^{-5} \mathrm{M}$ & $24.3 \pm 3.1^{8}$ \\
\hline & & RU $3848610^{-5} \mathrm{M}$ & $26.9 \pm 8.1$ \\
\hline
\end{tabular}

Cardiocytes were deinduced in medium containing 5\% serum substitute and 5\% "stripped" serum (5/5) for $72 \mathrm{~h}$ then changed to $10 \%$ serum substitute (for measurement of ANP immunoreactivity) or fresh 5/5 medium (for measurement of ANP mRNA levels) in the presence of the additives indicated for $24 \mathrm{~h}$. A 100- $\mu$ l aliquot of media was taken for the RIA. Cytoplasmic RNA was collected and analyzed as described in Methods. Results are expressed as mean \pm SD, $n=3$ for RIA, $n=4$ for RNA analyses. ${ }^{*} \alpha<0.01$ vs. Ctl; ${ }^{\star} \alpha<0.05$ vs. Dex $10^{-7} \mathrm{M}$; ${ }^{8} \alpha<0.01$ vs. Dex $10^{-6} \mathrm{M}$.

script (950-1050 nucleotides) levels (Fig. 2). RU 38486, a specific glucocorticoid antagonist, reduced both the increase in cellular ANP mRNA as well as the increase in secreted ANP protein seen after exposure to Dex (Table II).

Next, we attempted to determine whether Dex increased
A

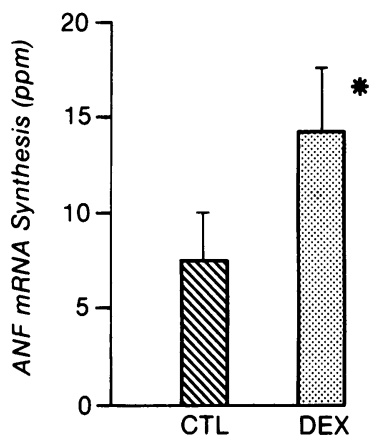

(4)
B

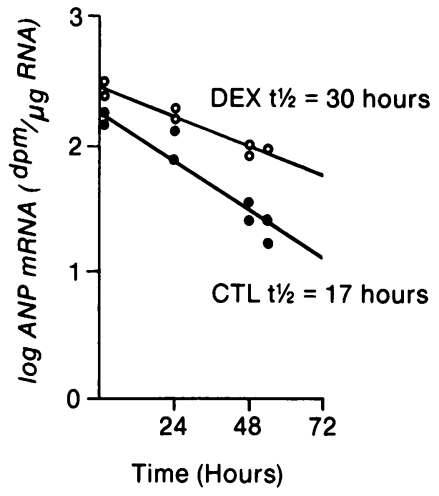

Figure 3. Transcriptional and posttranscriptional effects of Dex on expression of the ANP gene. $(A)$ Run-on transcription assay. Cardiocytes $\left(4 \times 10^{4}\right.$ cells) were deinduced for $72 \mathrm{~h}$ then exposed to fresh medium with (stippled bar) or without (striped bar) Dex $\left(10^{-6} \mathrm{M}\right)$ for $5 \mathrm{~h}$. Results are expressed as counts specifically hybridized to ANP filters per $10^{6} \mathrm{cpm}$ of input RNA and represent the mean \pm SEM for four independent determinations. Total bound counts, normalized for equivalent input and corrected for background, averaged 148 $\mathrm{cpm}$ in the control and $250 \mathrm{cpm}$ in the Dex-treated group. Nonspecific counts averaged $86 \mathrm{cpm}$ for the controls and $125 \mathrm{cpm}$ for the Dex-treated group. ${ }^{*} P<0.05$ assessed by ANOVA with NewmanKeuls test of significance. $(B)$ Pulse chase analysis. Cells $\left(5 \times 10^{6}\right)$ were deinduced for $48 \mathrm{~h}$ then exposed to fresh medium with (O) or without (๑) $10^{-6} \mathrm{M}$ Dex for an additional $24 \mathrm{~h}$. Cells were then pulsed with $1 \mathrm{mCi} / \mathrm{ml}\left[{ }^{3} \mathrm{H}\right]$ uridine and chased in the presence of unlabeled uridine and cytidine as described in the text. Labeled RNA was extracted at varying intervals into the chase and hybridized to nitrocellulose filters containing denatured ANP cDNA. Labeled ANP transcripts, corrected for nonspecific binding, are plotted as a function of time. Specific activity of the ANP transcripts at zero time were $171 \mathrm{dpm} / \mu \mathrm{g}$ total RNA for the control group and $296 \mathrm{dpm} / \mu \mathrm{g}$ total RNA for the Dex-treated group. Lines were drawn from linear regression analysis of the data. Half-lives were obtained directly from these regression data; slopes of the line were not statistically different by the Student's $t$ test.
ANP mRNA levels through a transcriptional versus posttranscriptional mechanism. We approached this question first using the "run-on" transcription technique, an in vitro assay which provides a semiquantitative measure of RNA-polymerase II molecules actively involved in transcribing the ANP gene in nuclei exposed to hormone in vivo. As shown in Fig. 3 $A$ Dex increased ANP gene transcription about twofold in nuclei from cells previously treated for $5 \mathrm{~h}$ with the steroid. We also assessed potential effects of Dex on ANP mRNA turnover (Fig. $3 \mathrm{~B}$ ) using conventional pulse-chase analysis. Based on this approach, a half-life of $17 \mathrm{~h}$ for the ANP transcript was obtained in the absence of the steroid. The half-life appeared to increase to $30 \mathrm{~h}$ in the presence of Dex, suggesting a posttranscriptional effect; however, the difference failed to reach statistical significance.

Since our primary cultures obviously represent a mixed population of cells, it is conceivable that Dex could increase ANP mRNA levels by recruiting nonexpressing myocardial cells into the expressing pool. To address this question we have employed the technique of in situ hybridization. As shown in Fig. 4, treatment of atrial-enriched myocardial cells resulted in an increase in the quantity of ANP mRNA per cell. Dex did not increase the number of expressing cells in the culture $(\mathrm{Ctl}$ $=31.3 \pm 7.4 \%$ cells $/ \mathrm{high}$ power field (hpf) vs Dex $10^{-7} \mathrm{M}$ $=27.3 \pm 9 \%$ cells $/ \mathrm{hpf}$; results presented as mean $\pm \mathrm{SD}$ ). This suggests that Dex acts to augment ANP gene activity in cells already expressing the gene and has little effect to recruit previously quiescent cells into the expressing pool.

\section{Discussion}

This study demonstrates that glucocorticoids act directly on myocardial cells to increase accumulation of transcripts from the rat ANP gene. This effect is dose dependent, is shared by both atrial as well as ventricular cardiocytes, shows glucocorticoid specificity, and is accompanied by increased secretion of immunoreactive peptide. At present it cannot be determined whether the effects on synthesis and secretion are causally related or independently regulated phenomena.

The predominant form of ANP released by these cells, either in the presence or absence of Dex, appeared to be $\simeq 17$ $\mathrm{kD}$ in size, corresponding to proANP as reported previously by others (31). However, given the much lower sensitivity of our RIA for proANP vs. ANP, we cannot exclude a modest effect 

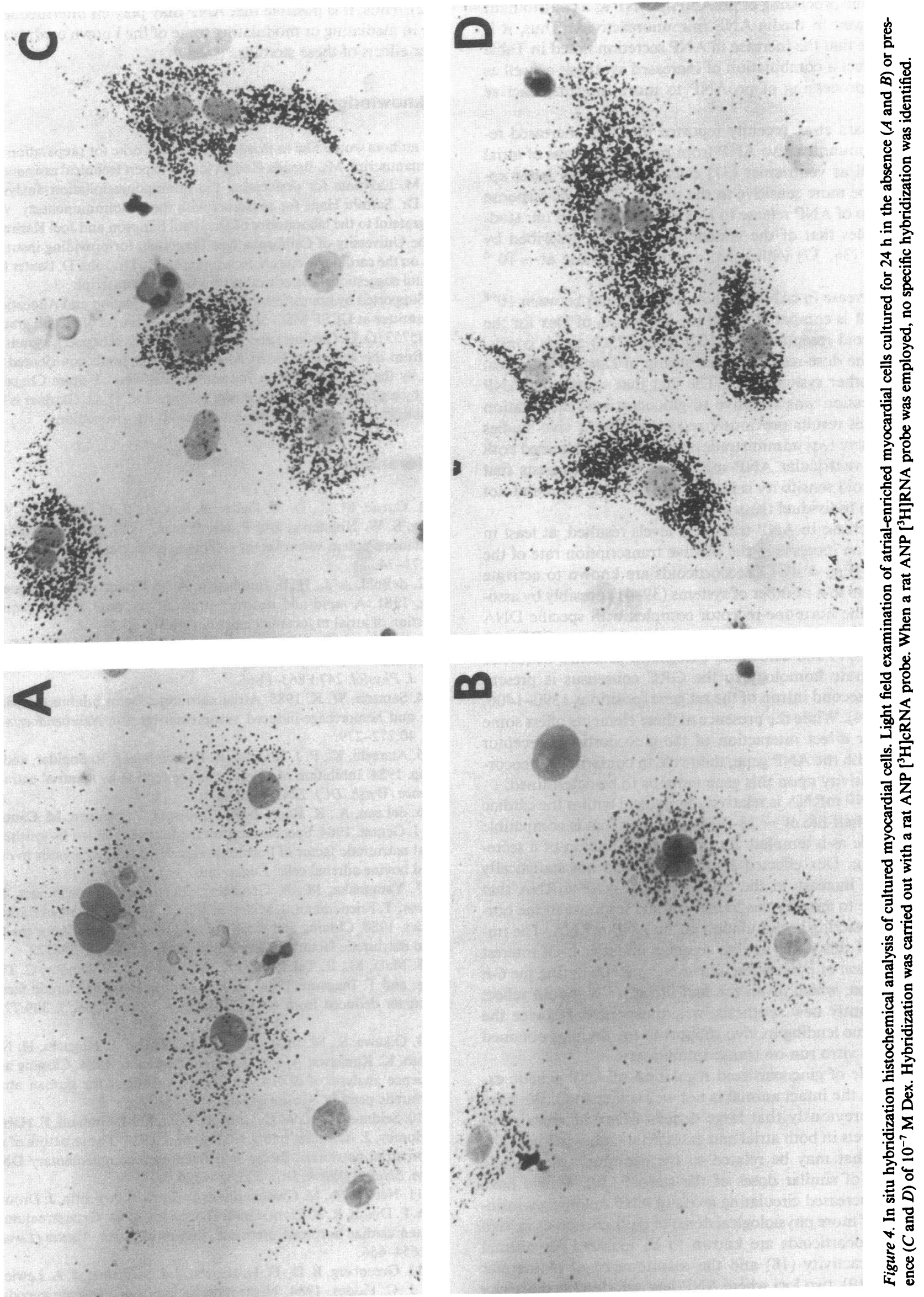
of Dex on the processing of proANP to ANP as a contributant to the increase in media ANP immunoreactivity. Thus, it is conceivable that the increase in ANP secretion noted in Table I could reflect a combination of increased synthesis as well as increased processing of proANP to more immunoreactive forms.

Matsubara et al. recently reported that Dex increased release of immunoreactive ANP from primary cultures of atrial (36) as well as ventricular (37) cells, although the latter appeared to be more sensitive to the steroid. The dose-response relationship of ANP release to Dex concentration in our studies resembles that of the ventricular cultures described by Matsubara $(36,37)$ with a half-maximal response at $\simeq 10^{-8}$ M Dex.

The increase in rANP mRNA accumulation between $10^{-8}$ and $10^{-6} \mathrm{M}$ is compatible with the known $K_{\mathrm{d}}$ of Dex for the glucocorticoid receptor $\left(K_{d} \simeq 10^{-8} \mathrm{M}\right.$ at $\left.37^{\circ} \mathrm{C}\right)$ and is consistent with the dose-response relationship of Dex for biological effects in other systems (37). The fact that ventricular ANP gene expression was sensitive to glucocorticoid stimulation substantiates results previously reported with in vivo studies $(22,23)$ where Dex administration to intact rats increased both atrial and ventricular ANP mRNA levels and suggests that glucocorticoid sensitivity is intrinsic to the gene itself and not confined to individual tissues.

The increase in ANP transcript levels resulted, at least in part, from an increase in the relative transcription rate of the ANP gene (Fig. $4 \mathrm{~A}$ ). Glucocorticoids are known to activate transcription in a number of systems (39-41) possibly by association of the hormone-receptor complex with specific DNA sequences (i.e., glucocorticoid responsive elements, GRE; references 15-17) and associated chromatin proteins. Sequence with moderate homology to the GRE consensus is present within the second intron of the rat gene (positions 1390-1406, reference 14). While the presence of these elements offers some support for direct interaction of the glucocorticoid receptor complex with the ANP gene, their role in conferring glucocorticoid sensitivity upon this gene remains to be determined.

The ANP mRNA is relatively long-lived within the cardiac cell with a half-life of $\sim 18-30 \mathrm{~h}$, a finding that is compatible with its role as a template for ongoing production of a secretory protein. Dex effected a modest, though not statistically significant, increase in the half-life of the ANP mRNA that could serve to amplify the transcriptional response to the hormone in fostering accumulation of the ANP mRNA. The importance of this effect in vivo remains undefined. Of interest incorporation of $\left[{ }^{3} \mathrm{H}\right]$ uridine into ANP mRNA during the 6-h pulse period, which given the half-life of $18 \mathrm{~h}$ should reflect predominantly new synthesis, was approximately twice the control value lending in vivo support to the findings obtained with the in vitro run-on transcription assay.

The role of glucocorticoid regulation of ANP genetic expression in the intact animal is not well understood. We have reported previously that large doses of Dex increase ANP mRNA levels in both atrial and extraatrial tissues in vivo (22), an effect that may be related to the prominent natriuretic properties of similar doses of the steroid (20). Others have reported increased circulating levels of ANP following administration of more physiological doses of glucocorticoids in vivo (21). Glucocorticoids are known to be required for normal vascular reactivity (18) and the maintenance of glomerular filtration (19), two loci where ANP has well-described activity
$(1,2)$. Thus, it is possible that ANP may play an intermediary role in mediating or modulating some of the known cardiovascular effects of these steroids.

\section{Acknowledgments}

The authors would like to thank Mrs. Susan Corke for preparation of the manuscript, Ms. Brenda Hedges for her expert technical assistance, Dr. M. LaPointe for performing the immunoprecipitation analyses and Dr. Satoshi Hane for assistance with the radioimmunoassay. We are grateful to the laboratories of Drs. Paul Simpson and Joel Karliner at the University of California, San Francisco, for providing instruction on the cardiocyte culture technique, and to Dr. John D. Baxter for helpful suggestions and critical review of the manuscript.

Supported by grants from the Research Evaluation and Allocation Committee at UCSF MSC-56; by National Institutes of Health grants HL35753 (D. G. Gardner) and HL38774 (C. F. Deschepper); a grant in aid from the American Heart Association with funds contributed in part by the American Heart Association Redwood Empire Chapter; and by a gift from California Biotechnology, Inc. D. G. Gardner is an Established Investigator of the American Heart Association.

\section{References}

1. Currie, M. C., D. M. Geller, B. R. Cole, J. C. Boylar, W. Yusheng, S. W. Holmberg, and P. Needleman. 1983. Bioactive cardiac substances: potent vasorelaxant activity in atria. Science (Wash. DC). 221:71-74.

2. deBold, A. J., H. B. Borenstein, A. T. Veress, and H. Sonnenberg. 1981. A rapid and potent natriuretic response to intravenous injection of atrial myocardial extract. Life Sci. 28:89-94.

3. Burnett, J. C., J. D. Granger, and T. J. Opgenarth. 1986. Effects of synthetic atrial natriuretic factor on renal function and renin release. Am. J. Physiol. 247:F863-F866.

4. Samson, W. K. 1985. Atrial natriuretic factor inhibits dehydration and hemorrhage-induced vasopressin release. Neuroendocrinology. 40:272-279.

5. Atarashi, K., P. J. Mulrow, R. Franco-Saenz, R. Snajdar, and J. Rapp. 1984. Inhibition of aldosterone production by an atrial extract. Science (Wash. DC). 224:992-994.

6. deLean, A., K. Racz, J. Gutkowska, T-T., Nguyen, M. Cantin, and J. Genest. 1984. Specific receptor mediated inhibition by synthetic atrial natriuretic factor of hormone-stimulated steroidogenesis in cultured bovine adrenal cells. Endocrinology. 115:1636-1638.

7. Yamanaka, M., B. Greenberg, L. Johnson, J. Seilhamer, M. Brewer, T. Friedemann, J. Miller, S. Atlas, J. Laragh, J. Lewicki, and J. Fiddes. 1984. Cloning and sequence analysis of the cDNA for the rat atrial natriuretic factor precursor. Nature (Lond.). 309:719-722.

8. Maki, M., R. Takayanaji, K. S. Misono, K. N. Pandey, C. Tibbetts, and $T$. Inagami. 1984. Structure of rat atrial natriuretic factor precursor deduced from cDNA sequence. Nature (Lond.). 309:722724.

9. Oikawa, S., M. Imai, A. Ueno, S. Tanaka, T. Noguchi, H. Nakazato, K. Kangawa, A. Fukada, and H. Matsuo. 1984. Cloning and sequence analysis of cDNA encoding a precursor for human atrial natriuretic peptide. Nature (Lond.). 309:724-726.

10. Seidman, C. E., A. D. Duby, E. Choi, R. M. Graham, E. Haber, C. Homcy, J. A. Smith, and J. G. Seidman. 1984. The structure of rat preproatrial natriuretic factor as defined by a complementary DNA clone. Science (Wash. DC). 225:324-326.

11. Nemer, M., M. Chamberland, D. Sirois, S. Argentin, J. Drouin, R. A. F. Dixon, R. A. Zivin, and J. H. Condra. 1984. Gene structure of human cardiac hormone precursor, pronatriodilatin. Nature (Lond.). 312:654-656.

12. Greenberg, B. D., G. H. Bencen, J. J. Seilhamer, J. A. Lewicki, and J. C. Fiddes. 1984. Nucleotide sequence of the gene encoding 
human atrial natriuretic factor precursor. Nature (Lond.). 312:656658.

13. Seidman, C. E., K. D. Bloch, K. A. Klein, J. A. Smith, and J. G. Seidman. 1984. Nucleotide sequences of human and mouse atrial natriuretic factor genes. Science (Wash. DC). 226:1206-1209.

14. Argentin, S., M. Nemer, J. Drouin, G. K. Scott, B. P. Kennedy, and P. L. Davies. 1985. The gene for rat atrial natriuretic factor. J. Biol. Chem. 260:4568-4571.

15. Payvar, F., D. DeFranco, G. Firestone, B. Edgar, O. Wrange, S. O'Kret, J. A. Gustafsson, and K. R. Yamamoto. 1983. Sequence specific binding of glucocorticoid receptor to MMTV DNA at sites within and upstream of the transcribed region. Cell. 35:381-392.

16. Karin, M., A. Harlinger, H. Holtgreve, R. I. Richards, P. Krauter, H. M. Westphal, and M. Beato. 1984. Characterization of DNA sequences through which cadmium and glucocorticoid hormones induce human metallothionein $\mathrm{II}_{\mathrm{A}}$ gene. Nature (Lond.). 308:513-519.

17. Slater, E. P., O. Rabenau, M. Karin, J. D. Baxter, and M. Beato. 1985. Glucocorticoid receptor binding and activation of a heterologous promoter by dexamethasone by the first intron of the human growth hormone gene. Mol. Cell. Biol. 5:2984-2992.

18. Lefer, A. M. 1985. Handb. Physiol. Endocrinology. Adrenal gland. Sec. 7:191-207.

19. Bengele, H. H., E. R. McNamara, and E. A. Alexander. 1977. Natriuresis after adrenal enucleation: effects of spironolactone and dexamethasone. Am. J. Physiol. 233(1):F8-F12.

20. Grunfeld, J.-P., L. Eloy, A. M. Moura, D. Ganeval, B. RamosFrendo, and M. Worcel. 1983. Effects of antiglucocorticoids on glucocorticoid hypertension in the rat. Hypertension. 7:292-299.

21. Garcia, R., W. Debinski, J. Gutkowska, O. Kuchel, G. Thibault, J. Genest, and M. Cantin. 1985. Gluco- and mineralocorticoids may regulate the natriuretic effect and the synthesis and release of atrial natriuretic factor by rat atria in vivo. Biochem. Biophys. Res. Commun. 131:806-814.

22. Gardner, D. G., S. Hane, D. Trachewsky, D. Schenk, and J. D. Baxter. 1986. Atrial natriuretic peptide mRNA is regulated by glucocorticoids in vivo. Biochem. Biophys. Res. Commun. 139:1047-1054.

23. Day, M. L., Schwartz, D. Wiegand, R. C. Stockman, P. T., Brunnert, S. R., Tolunay, H. E., Currie, M. G., Standaert, D. G. and Needleman, P. 1987. Ventricular atriopeptin: Unmasking of mRNA and peptide synthesis by hypertrophy or dexamethasone. Hypertension. 9:485-491.

24. Simpson, P., and S. Savion. 1982. Differentiation of rat myocytes in single cell cultures with and without proliferating nonmyocardial cells. Circ. Res. 50:101-116.

25. Bauer, R. F., L. O. Arthur, and D. L. Fine. 1976. Propagation of mouse mammary tumor cell lines and production of mouse mammary tumor virus in serum-free medium. In Vitro. 12:558-563.

26. Dobner, P. R., E. S. Kawasaki, L. Yu, and F. C. Bancroft. 1981. Thyroid or glucocorticoid hormone induces pro-growth hormone mRNA and its probable nuclear precursor in rat pituitary cells. Proc. Natl. Acad. Sci. USA. 78:2230-2234.

27. Gardner, D. G., C. S. Deschepper, W. F. Ganong, S. Hane, J. Fiddes, J. D. Baxter, and J. Lewicki. 1986. Extra-atrial expression of the gene for atrial natriuretic factor. Proc. Natl. Acad. Sci. USA. 83:6697-6701.

28. Thomas, P. S. 1980. Hybridization of denatured RNA and small DNA fragments transferred to nitrocellulose. Proc. Natl. Acad. Sci. USA. 77:5201-5205.

29. Berent, S. L., M. Mahmoudi, R. M. Torczynski, P. W. Bragg, and A. P. Bollon. 1985. Comparison of oligonucleotide and long DNA fragments as probes in DNA and RNA dot, Southern, Northern, colony and plaque hybridizations. Biotechniques. 3:208-220.

30. Schwartz, D., D. M. Geller, P. T. Manning, N. R. Siegel, K. F. Fok, C. E. Smith, and P. Needleman. 1985. Ser-Leu-Arg-Arg-Atriopeptin III: the major circulating form of atrial peptide. Science (Wash. DC). 229:397-400.

31. Bloch, K. D., J. A. Scott, J. B. Zisfein, J. T. Fallon, N. M. Margolis, C. E. Seidman, G. R. Matsueda, C. J. Homcy, R. M. Graham, and J. G. Seidman. 1985. Biosynthesis and secretion of proatrial natriuretic factor by cultured rat cardiocytes. Science (Wash. DC). 230:1168-1171.

32. Matrisian, L. M., N. Glaichenhaus, M. Gsnel, and R. Breathnach. 1985. Epidermal growth factor and oncogenes induce transcription of the same cellular RNA in rat fibroblasts. Eur. Mol. Biol. Organ. J. 4:1435-1440.

33. Maxwell, J. N., J. Van Ness, and W. E. Hahn. 1978. Assay of DNA-RNA hybrids by $S_{1}$ nuclease digestion and absorption to DEAE-cellulose filters. Nucl. Acids Res. 5:2033-2038.

34. Kafatos, F. C., W. C. Jones, and A. Efstratiadis. 1979. Determination of nucleic acid sequence homologies and relative concentrations by a dot hybridization procedure. Nucl. Acids Res. 7:1541-1552.

35. McKnight, G. S., and R. D. Palmiter. 1979. Transcriptional regulation of the ovalbumin and conalbumin genes by steroid hormones in chick oviduct. J. Biol. Chem. 254:9050-9058.

36. Matsubara, N., Y. Hirata, W. Yoshima, S. Takata, Y. Takagi, T. Iida, Y. Yamane, Y. Umeda, M. Nishikawa, and M. Inada. 1987. Effect of steroid and thyroid hormones on synthesis of atrial natriuretic peptide by cultured atrial myocytes of rat. Biochem. Biophys. Res. Commun. 145:336-343.

37. Matsubara, N., Y. Hirata, H. Yoshimi, S. Takata, Y. Takagi, Y. Yamane, Y. Umeda, M. Nishikawa, and M. Inada. 1987. Ventricular myocytes from neonatal rats are more responsive to dexamethasone than atrial myocytes in synthesis of atrial natriuretic peptide. Biochem. Biophys. Res. Commun. 148:1030-1038.

38. Bloom, E., D. T. Matulich, N. C. Lan, S. J. Higgins, S. S. Simons, and J. D. Baxter. 1980. Nuclear binding of glucocorticoid receptors: relations between cytosol binding, activation and biological response. J. Steroid Biochem. 12:175-184.

39. Hager, L. J., and R. D. Palmiter. 1981. Transcriptional regulation of mouse liver metallothionein-I gene by glucocorticoids. Nature (Lond.). 291:340-342.

40. Spindler, S. R., S. H. Mellon, and J. D. Baxter. 1982. Growth hormone gene transcription is regulated by thyroid and glucocorticoid hormones in cultured rat pituitary tumor cells. J. Biol. Chem. 257:11627-11632.

41. Danesch, U., S. Hashimoto, R. Kerkawitz, and G. Schutz. 1983. Transcriptional regulation of the tryptophan oxygenase gene in rat liver by glucocorticoids. J. Biol. Chem. 258:4750-4753. 